These experiments show that an association of the complex cation with the metallic cation occurs, the ligand $X$ acting as a bridge between the two metals. In the ionpair formed a certain fraction of electron density is transferred to the bond $M-X$, so that the bond $X-$ Co is loosened which facilitates the aquation. The electrochemical reduction of the ion-pair does not proceed via the aquated ion or via a particle with the co-ordination number 5 , for the rate of reduction is higher than it would correspond to a process preceded by a homogeneous splitting off the ligand $X$.

\section{A. A. VLČEK}

Polarographic Institute,

Czechoslovak Academy of Sciences, Prague.

2 Vlcek, A. A., Dise. Farad. Soc., No. 29, 114 (1960).

2 Vlrek, A. A., Advances in the Chemistry of the Coordination Compounds, edit. by Kirschner, S., 590 (Macmillan Co., New York, 1961).

${ }^{3}$ Kuta, J., and Smoler, I., Z. Elektrochem., 64, 285 (1960).

${ }^{4}$ Posey, F. A., and Taube, A., J. Amer. Chem. Soc., 79, 255 (1957).

\section{Evaporation of Langmuir - Blodgett Monolayers in Vacuum}

WHILE there is an extensive literature on the methods of depositing monomolecular films of fatty substances on solid surfaces by the Langmuir-Blodgett method ${ }^{\mathbf{x}}$, there seems to be little information available on the stability of the films once prepared. Gregg and Widdowson ${ }^{2}$ studied the evaporation of built-up multilayers of fatty acids, but their results were restricted to layers many molecules thick. More recently, Karle ${ }^{3}$ and Menter and Tabor ${ }^{4}$ have obtained some evidence of the evaporation of fatty acid and soap molecules from monomolecular films in electron. diffraction investigations.

The availability of radioactively labelled fatty acids in recent years has permitted a more direct approach to assessing the stability of such deposited monolayers. We have recently reported observations on the stability in vacuo of stearic acid and barium-copper stearate monolayers deposited on quartz, soft glass and gold ${ }^{5}$. The monolayers were labelled with carbon-14, and the rate at which they were desorbed at room temperature and a pressure of $\sim 10^{-6}$ torr was measured radiometrically. The barium-copper stearate films on soft glass lost about 10 per cent of their initial activity in $90 \mathrm{~h}$ pumping; stearic acid films on gold, on the other hand, were about half removed after $5 \mathrm{~h}$ evacuation. These investigations have now been extended.

The most stable monolayers which we have prepared are those of $n$-octadecylamine hydrochloride, deposited on either mica or evaporated gold films from the surface of $10^{-3} \mathrm{~N}$ hydrochloric acid. Such monolayers retain more than 90 per cent of their initial activity after $40 \mathrm{~h}$ of evacuation. Autoradiographs of these monolayers, both before and after evacuation, show a uniform density of activity over the entire sample. We have found the deposition of $n$-octadecylamine hydrochloride monolayers, however, to be more erratic than that of the stearates, perhaps partly due to the greater tendency to expansion of the amine hydrochloride monolayers on the aqueous surface $^{6}$; we have also found evidence of slow solution of these monolayers while spread on the acid subphase. In several cases, we have obtained transferred monolayers, the initial activity of which was appreciably below that to be expected from a homogenoous monolayer; autoradiographs of the samples show an inhomogeneous distribution of activity over the surface. The free amine, spread on $10^{-3} \mathrm{~N}$ sodium hydroxide solutions, should form a more compact monolayer ${ }^{7}$. We have prepared a few samples of free $n$-octadecylamine monolayers on gold, quartz, and mica, and their stability in vacuum appears to be appreciably lower than that of the corresponding amine hydrochloride films. This result is not surprising, since the free amines have much lower melting points and higher. vapour pressures than do their salts.

For many types of experiments, only short-term stability to vacuum exposure may be required. The removal of the first small fraction of a monomolecular film may be governed by factors quite different from those controlling the removal of the major portion of the monolayer. In the case of soap monolayers, for example, it is possible that any free fatty acid in the film would evaporate more readily than the soap itself ${ }^{2}$.

Table 1. Short-Thrm Stabihty of Monolayers in Vacuum. Fraction of Monolayer remaining after 30 min PUMring is Tabdlated. MonoLAYERS WERE DEPOSITED UNDER 17 DYNES/CM SURFACE PRESSURF

\begin{tabular}{|c|c|c|c|c|c|}
\hline Substrate & Quartz & Mica & $\begin{array}{l}\text { Soft } \\
\text { glass }\end{array}$ & $\begin{array}{l}\text { Gold on } \\
\text { quartz }\end{array}$ & $\begin{array}{c}\text { Gold on } \\
\text { mical }\end{array}$ \\
\hline $\begin{array}{l}\text { Monolayer } \\
\text { Barium-copper } \\
\text { stearate }\end{array}$ & $\begin{array}{c}0.93 \pm 0.02 \\
(4)\end{array}$ & $0.97 \underset{(5)}{ \pm 0.03}$ & $\begin{array}{c}0.95 \pm 0.02 \\
\text { (3) }\end{array}$ & $0.94 \underset{(3)}{ \pm 0.01}$ & $0.91+0.04$ \\
\hline Stearic acid & $0 \cdot 31 \underset{(2)}{ \pm} 0 \cdot 04$ & - & - & $0 \cdot 85+0 \cdot 01$ & $\ldots$ \\
\hline $\begin{array}{l}\text { i-Octadecylami } \\
\text { hydrochlorid }\end{array}$ & ine 2$)$ & $1 \cdot 00 \underset{(4)}{ \pm 0.02}$ & 一 & (2) & $0 \cdot 96)_{(4)}^{-1.0 \cdot 01}$ \\
\hline
\end{tabular}

In order to investigate this behaviour, we examined a number of samples after they had been exposed to vacuum for $30 \mathrm{~min}$. The results are presented in Table 1. Both barium-copper stearate and n-octadecylamine hydrochloride monolayers are fairly stable over this short period ; stearic acid films have already lost an appreciable amount of their activity in $30 \mathrm{~min}$. Mica substrates seem to show the highest resistance to desorption of the solids which we have used, although the differences observed with the barium-copper stearate and $n$-octyldecylamine hydrochloride monolayers are small.

George L. Garnes, Jun.

Richard W. Roberts

General Electric Research Laboratory, Schenectady, New York.

${ }^{1}$ Langmuir, I., Trans. Faraday Soc, 15, $62(1920)$. Blodgett, K. B., J. Amer Chem. Soc., 56, 495 (1934); ibid., 57, 1007 (1935).

2 Gregg, S. J., and Widdowson, E. E., Nature, 144, 666 (1939).

${ }^{3}$ Karle, J., J. Chem. Phys., 17, 500 (1949).

'Menter, J. W., and Tabor, D., Proc. Roy. Soc., A, 204, 514 (1951).

- Roberts, R. W., and Gaines, G. L., jun., Trans. Nat. Vacuum Symp. 196: (in the press).

${ }^{B}$ Hoffman, E. J., Boyd, G. E., and Y:alston, A. W., J. Amer. Chem. Soc., 64, 498 (1942).

${ }^{7}$ Adam, N. K., Proc. Roy. Soc., A, 126, 526 (1930).

\section{Schmidt Reaction}

Since the advent of commercial polyphosphoric acid, a number of novel procedures have been developed for the Schmidt reaction using polyphosphoric acid as the solvent and catalyst ${ }^{1-5}$.

It was intoresting to note that in nearly all the reactions run, temperatures of $100^{\circ}$ or highor were used. One of these ${ }^{5}$ reported that benzoic acid gave aniline in 48 per cont yield, along with a considerable amount of diphenylurea, while $p$-nitrobenzoic acid failed to react. The conditions of these reactions were not clearly defined.

We found that aromatic carboxylic acids can be converted to the corresponding amines at room temperature $\left(25^{\circ}\right)$ in good yields using polyphosphoric acid and oxcess sodium azide. Table 1 shows our results. The yields are in agreement with the fact that acids with electron donator groups give better yiclds and have faster rates ${ }^{6}$.

\begin{tabular}{|c|c|c|c|c|c|}
\hline \multicolumn{6}{|c|}{ Table 3} \\
\hline Acid & Product & $\begin{array}{l}\text { Yield } \\
(\%)\end{array}$ & Derivative & $\begin{array}{c}\text { Melting } \\
\text { point }\end{array}$ & Infra-red \\
\hline Benzoic & Aniline & $71 \cdot 2$ & Benzamide & $161-162^{\circ}$ & $2 \cdot 82,2 \cdot 91,3 \cdot 08$ \\
\hline $\begin{array}{l}p \text {-Nitro- } \\
\text { benzoic }\end{array}$ & $\begin{array}{l}p \text {-Nitro- } \\
\text { aniline }\end{array}$ & $48 \cdot 2$ & - & $146^{\circ}$ & $\begin{array}{l}2 \cdot 82,2 \cdot 94,3.09 \text {, } \\
6 \cdot 19,7 \cdot 72 \mu\end{array}$ \\
\hline $\begin{array}{l}p \text {-Methoxy- } \\
\text { benzoic }\end{array}$ & $\begin{array}{l}p \text {-Methoxy- } \\
\text { aniline }\end{array}$ & $79 \cdot 7$ & - & $55-56^{\circ}$ & $\begin{array}{l}2 \cdot 82,2 \cdot 91,3 \cdot 07 \text {, } \\
6 \cdot 17,7 \cdot 70 \mu\end{array}$ \\
\hline Mesitoic & Mesidine & $90 \cdot 6$ & Benzamide & $203^{\circ}$ & $\begin{array}{l}2 \cdot 83,2 \cdot 90,3.07 \\
6 \cdot 18,7 \cdot 70 \mu \text { (film) }\end{array}$ \\
\hline
\end{tabular}

